\author{
Sławomir Czapnik \\ Uniwersytet Opolski
}

\title{
Konflikt izraelsko-palestyński. Analiza nekropolityczna
}

DOI: $10.19195 / 1643-0328.22 .12$

Słowa kluczowe: Palestyńczycy, Izrael, konflikt polityczny, nekropolityka

\section{Wprowadzenie}

Jak zauważa Achille Mbembe, który ukuł termin „nekropolityka” (necropolitics), ostatecznym wyrazem suwerenności jest władza i możliwość dyktowania, kto może żyć, a kto musi umrzeć. Zabijanie lub zgoda na życie konstytuuje granice suwerenności. Sprawowanie suwerenności oznacza kontrolowanie śmiertelności i definiowanie życia jako przejawu władzy ${ }^{1}$. Okupacja kolonialna późnej nowoczesności pod wieloma względami różni się od jej wczesnonowoczesnej odmiany, szczególnie w wymiarze dyscypliny, biopolityki i nekropolityki. Najlepszym przykładem współczesnej okupacji kolonialnej jest okupacja Palestyny. To kolonialne państwo podkreśla swoją suwerenność i legitymizację poprzez szczególną narrację o dziejach i tożsamości, wywodzonej z idei boskiego prawa do istnienia. Zderza się ona jednak $z$ inną narracją i $z$ innymi roszczeniami do tej samej świętej przestrzeni. Obie narracje są rozbieżne, a populacje, których dotyczą, są wymieszane, zatem jakiekolwiek rozgraniczenie terytoriów na podstawie czystej tożsamości jest niemożliwe. Narodowa tożsamość jest tożsamością wymierzoną w Innego. Historia, geografia, kartografia i archeologia mają wesprzeć powyższe roszczenia, wiążąc nierozerwalnie tożsamość z topografią. Kolonialna przemoc i okupacja są wpisane w „święty terror prawdy” i wyłączności - dowodzą tego masowe wysiedlenia, umieszczenie bezpaństwowców w obozach dla uchodźców, tworzenie nowych kolonii. Narzędziem dominacji staje się oryginalna zbrodnia - terror Zagłady².

Kategoria nekropolityki stanowi rozwinięcie rozważań dotyczących biopolityki i biowładzy. Pojęcie biopolityki zostało użyte w roku 1905 przez szwedzkiego politologa Ru-

\footnotetext{
1 A. Mbembe, Necropolitics, „Public Culture” 15, 2003, nr 1, s. 11-12.

2 Ibidem, s. 27.
} 
dolfa Kjelléna, autora odwołującego się do organicystycznej wizji państwa ${ }^{3}$. Dla Michela Foucaulta biopolityka, której biowładza jest narzędziem, to typowy dla nowoczesności sposób sprawowania władzy nad ludźmi, postrzeganymi nade wszystko jako byty biologiczne, cielesne ${ }^{4}$. Z kolei Giorgio Agamben w kontekście biopolityki posługuje się kategorią "nagiego życia” - jego zdaniem już Hobbesowska metafora państwa jako Lewiatana, nowego ciała politycznego Zachodu, składała się z „absolutnie dających się zabić ciał poddanych"5.

Można przypuszczać, że konflikt izraelsko-palestyński zyskuje pewną przejrzystość, jeśli odwróci się logikę „,dekontekstualizacji”, którą stworzył neokonserwatywny teoretyk i doradca izraelskiego Likudu Richard Perle. Miała ona wyjaśniać desperackie akty terroryzmu w ogóle i oporu zbrojnego Palestyńczyków wobec okupacji. Perle podkreślał, że globalną krytykę traktowania przez Izrael Palestyńczyków, ich opór wobec okupacji należy dekontekstualizować, nie troszcząc się o zrozumienie względów terytorialnych, geopolitycznych i historycznych, które skłaniają pewne grupy do sięgnięcia po taktyki terrorystyczne. Korzeni przemocy należy doszukiwać się w sferach kultury i religii $\mathrm{w}$ islamskim sposobie myślenia. Innymi słowy, winę ponoszą „patologiczne problemy muzułmańskiego umysłu" . Rzecz jasna, Perle nie wspomina o zawartych w judaizmie koncepcjach „narodu wybranego” jako jednym ze źródeł konfliktu.

Rozważania niniejsze składają się z dwóch części. W pierwszej analizuje się medialny wizerunek konfliktu izraelsko-palestyńskiego, ze szczególnym uwzględnieniem opiniotwórczych mediów amerykańskich i brytyjskich, próbując go skonfrontować z miejscowymi realiami. W drugiej zwraca się uwagę na pewne formacje dyskursywne, które powodują, że dane akty przemocy uznaje się za usprawiedliwione, konieczne, słowem: czyste, inne zaś budzą estetyczną odrazę i moralny sprzeciw.

\section{Medialny obraz konfliktu izraelsko-palestyńskiego}

Walter Lippman rozpoczął swoją książkę Public Opinion od konstatacji o ograniczoności horyzontów myślowych „zwykłych” ludzi, którzy ufają medialnym „obrazom w swoich

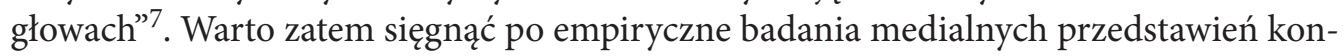
fliktu izraelsko-palestyńskiego, ze szczególnym uwzględnieniem badania dokonanego przez Glasgow University Media Group (GUMG), która przeanalizowała główne brytyjskie programy informacyjne BBC i ITV. Obie stacje, zwłaszcza ta pierwsza - publiczna, uchodzą za nader rzetelne, szczycąc się obiektywizmem i neutralną reprezentacją najbardziej nawet kontrowersyjnych tematów.

3 T. Lemke, Biopolityka, Warszawa 2010, s. 17.

${ }^{4}$ M. Foucault, Urządzanie ciat, czyli władza w epoce biopolityki, Warszawa 2010; idem, Narodziny biopolityki, Warszawa 2011.

5 G. Agamben, Homo sacer. Suwerenna władza i nagie życie, Warszawa 2008, s. 172.

6 I. Hossein-Zadeh, The Political Economy of U.S. Militarism, New York-Basingstoke 2006, s. 100-101.

7 W. Lippmann, Public Opinion, New York 1922. 
Judith Butler zastanawia się, czy trwanie lub eskalowanie wojny byłoby możliwe bez uprzedniego przygotowania i ustrukturyzowania publicznego pojmowania wojny, bez starań o wyeliminowanie wszelkich wizualnych, słuchowych czy narracyjnych jej przedstawień, które mogłyby stać się zarzewiem masowych protestów antywojennych. Telewizyjne sprawozdania z wojny ustawiają obywateli na pozycji wizualnych konsumentów pełnego przemocy konfliktu, który toczy się zupełnie gdzie indziej ${ }^{8}$.

Odniesienie się do Jerozolimy i kontroli nad tym miastem jest częste $\mathrm{w}$ doniesieniach telewizyjnych, lecz jest ono zwykle tak pobieżne, że nie ma większego sensu dla kogoś, kto już wcześniej nie orientował się w bliskowschodniej polityce. Dla większości odbiorców idzie o spór dwóch grup ludzi o święte miasto, nad którym pragnęliby zawiesić swój sztandar. Okazuje się, że wielu widzów postrzega ten konflikt właśnie w kategoriach dwóch grup sąsiadów, które nie mogą się porozumieć ${ }^{9}$.

W brytyjskich stacjach telewizyjnych powtarzano, że wielu Palestyńczyków nie wierzy w uczciwość Amerykanów jako mediatorów w konflikcie z Izraelem. Nie wspominano jednak o powodach takiego stanowiska. A wśród nich można wymienić coroczną pomoc Stanów Zjednoczonych dla Izraela w wysokości 3 miliardów dolarów, w dużej części przybierającą postać uzbrojenia - Amerykanie dostarczają broń jednej ze stron konfliktu. Obrazom Palestyńczyków palących amerykańską flagę bardzo rzadko towarzyszy informacja, że Stany Zjednoczone dostarczają broni, której w atakach używają Izraelczycy ${ }^{10}$. Należy uwypuklić, że szczegółowe analizy medialnych doniesień amerykańskich mediów dość jednoznacznie wskazują, iż generalnie są one przychylne Izraelowi i niechętne Palestyńczykom. Mohamad Elmasry, który badał nagłośnienie drugiej intifady na łamach „New York Timesa” i „Chicago Tribune”, podkreśla, że przemoc izraelską ukazywano w kategoriach „samoobrony” (self-defense) i „wojny” (war), podczas gdy przemoc palestyńską ujmowano jako „agresję” (aggresion) i „przestępczość” (criminality); oba dzienniki sięgały częściej po źródła izraelskie niż palestyńskie ${ }^{11}$. Badanie „New York Timesa” w różnych okresach (lata 1987-1988, 2000-2001 i po 11 września 2001 r.) unaocznia nie tylko proizraelską tendencję, lecz wskazuje ponadto, iż wraz z upływem czasu ta tendencja przybiera na sile; przykładem tego może być skłonność do personalizowania ofiar śmiertelnych po stronie izraelskiej, przy jednoczesnym ignorowaniu zabitych Palestyńczyków ${ }^{12}$. Establishment medialny odzwierciedla wieloletnią politykę amerykańską - w latach 1967-2008 Stany Zjednoczone zawetowały 84 rezolucje ONZ, które potępiały politykę izraelską lub działania państwa żydowskiego na terytoriach okupowanych ${ }^{13}$.

8 J. Butler, Ramy wojny. Kiedy życie godne jest opłakiwania?, Warszawa 2011, s. 19.

9 G. Philo, M. Berry, Bad News from Israel, London-Sterling VA 2004, s. 103.

10 Ibidem, s. 106.

11 M. Elmasry, Death in the Middle East: An analysis of how the New York Times and Chicago Tribune framed killings in the second Palestinian Intifada, http://www2.gsu.edu/ wwwaus/Elmasry2009.pdf (dostęp: 30 sierpnia 2016).

12 M. Viser, Attempted objectivity. An analysis of the New York Times and Haiaretz and their portrayals of the Palestinian-Israeli conflict, „The International Journal of Press/Politics” 8, 2003, nr 4, s. 114-120.

13 J. Halper, An Israeli in Palestine. Resisting Dispossession, Redeeming Israel, London 2008, s. 148. 
Wyjaśnienie korzeni kryzysu palestyńsko-izraelskiego wymaga poinformowania publiczności o dwóch kluczowych sekwencjach zdarzeń. Po pierwsze, kiedy stworzono Izrael w 1948 r., wielu Palestyńczyków musiało opuścić swoje domy i stali się oni uchodźcami. Po drugie, wielu z tych uchodźców żyje na Zachodnim Brzegu Jordanu, w Jerozolimie Wschodniej i Gazie - terenach okupowanych po wojnie z 1967 r. Palestyńczycy sprzeciwiają się wojskowej kontroli izraelskiej. Kiedy wybuchła druga intifada, autorzy niektórych newsów nie wspominali, że wybuchła ona na terytoriach okupowanych, określając je mianem Izraela. Wśród doniesień medialnych czołowych brytyjskich telewizji między 28 września a 16 października 2000 r., których transkrypcja przekroczyła ogółem 3,5 tysiąca linijek tekstu, zaledwie 17 z nich odnosiło się do historii konfliktu. Nie jest zatem niespodzianką, że zdecydowana większość badanych widzów nie miała pojęcia, skąd wzięli się uchodźcy i jak stali się oni uchodźcami. Media relacjonowały niekiedy drugą intifadę jako „samonapędzającą się tragedię" (self-perpetuating tragedy), logikę „wet za wet” (tit-for-tat), wzajemne „odpowiedzi” (response) i „odwet” (revenge). Bezdyskusyjne jest stwierdzenie, że przemoc rodzi przemoc, eskalując wrogość. Jednakże w takiej perspektywie nie sposób wytłumaczyć korzeni konfliktu: nie można przecież dopatrywać się sensu drugiej wojny światowej w tym, że Wielka Brytania i Niemcy nawzajem się bombardowały. Źródła konfliktu i to, co z nich wynika dla potencjalnego rozwiązania, nie mogą być zrozumiane przez codzienne doniesienia o wydarzeniach i odpowiedziach na nie ${ }^{14}$.

Wpływ, jaki wywiera okupacja na codzienne życie Palestyńczyków, praktycznie nie jest przedstawiany w mediach. Normalnie nie używa się takich określeń, jak „okupacja zbrojna” (military occupation) czy „rządy wojskowe” (military rule), tymczasem skutki obecności żołnierzy i żołnierek izraelskich na terytoriach palestyńskich to główny czynnik niepokojów. Jak ujęła to izraelska grupa praw człowieka B’Tselem z okazji 50. rocznicy Powszechnej deklaracji praw człowieka: „Być może za wyjątkiem artykułu o niewolnictwie, Państwo Izrael łamie wszystkie reguły Deklaracji wobec Palestyńczyków”. B’Tselem ujawniło, że zabójstwa Palestyńczyków przez osadników są rzadko karane. Co więcej, spośród 1000-1500 palestyńskich więźniów przesłuchiwanych przez Szin Bet $85 \%$ było torturowanych ${ }^{15}$. Było to przed drugą intifadą, zanim palestyńskie służby bezpieczeństwa zaczęły współpracować z Izraelem, aby aresztować dysydentów i wrogów porozumień między Izraelczykami a Jaserem Arafatem. 13 różnych palestyńskich służb bezpieczeństwa wzorowało się na Szin Bet, trzy czwarte zatrzymanych przez nie było zaś torturowanych. $\mathrm{W}$ tym samym czasie tysiące Palestyńczyków przebywały w izraelskich więzieniach, niektórzy od czasu pierwszej intifady z 1987 r. Z punktu widzenia Palestyńczyków Izraelczycy używali pokoju, aby poszerzyć swoją wojskową i gospodarczą dominację. Palestyńczykom coraz trudniej było się poruszać, gdyż nowe osiedla łączyły drogi, po których poruszać się mogli wyłącznie Izraelczycy. Wiązało się to ze zniszczeniem buldożerami dużych połaci ziemi i rozwojem systemu punktów kontrolnych. Osoby, które na własne oczy przekonały się, jak wygląda życie Palestyńczyków, często

\footnotetext{
14 G. Philo, M. Berry, op. cit., s. 108-113.
}

15 Ibidem, s. 116. 
podkreślały ograniczenia wiedzy czerpanej ze środków masowego przekazu. Pewnego biznesmena, który prowadził interesy na Bliskim Wschodzie, często podróżując do Izraela i Zachodniego Brzegu, rozgniewała „izraelska brutalność, rasizm i hipokryzja”; to stanowisko podzielali również niektórzy Żydzi ${ }^{16}$.

Dziennikarze po wielokroć powtarzają, że dane miejsce przypomina nie osadę, lecz fortecę - w gruncie rzeczy, choć bezwiednie, trafnie oddawali istotę problemu. Celem żydowskiego osadnictwa jest utrzymanie nie tylko strategicznej i wojskowej kontroli, lecz zawładnięcie ziemią i zasobami wody. Jednakże przekazy skupiają się na zagrożeniach, na które wystawieni są osadnicy, prezentując Palestyńczyków i Izraelczyków jako dwie walczące z sobą wspólnoty. Niewyjaśniona zostaje — zaznacza GUMG — kluczowa kwestia, a mianowicie strukturalny podział społeczeństwa - jedna grupa skutecznie kontroluje życie drugiej (co spotyka się z pewnym oporem). Przekazy często skupiają się na „bronieniu” (defending) i „chronieniu” (protecting) „małych żydowskich enklaw”, o Arabach mówi się zaś, że „kontynuują rzeź”. Nawet jeżeli wspomina się, że Palestyńczycy postrzegają osiedla jako symbol izraelskiej okupacji, nie tłumaczy się, co faktycznie ona oznacza dla Palestyńczyków, toteż ich motywacje można sprowadzić do żywionej przez nich nienawiści. Wśród różnorakich form aktywności osadników wymierzonej w Palestyńczyków można wymienić - za B’Tselem - tworzenie blokad drogowych, aby utrudnić Arabom życie, niszczenie samochodów, wybijanie szyb, niszczenie upraw i wyrywanie drzew z korzeniami, zastraszanie palestyńskich właścicieli i sprzedawców na targowiskach ${ }^{17}$.

Kiedy amerykańska badaczka Maia Carter Hallward powróciła do Izraela i Palestyny w 2003 r. (była tam kilka lat wcześniej), znalazła krajobraz odmieniony przez drugą intifadę. Zbudowano nowe drogi między osiedlami, aby okrążyć społeczności palestyńskie. Nowe punkty kontrolne przecinały drogi między miastami - trzeba było jechać trzema taksówkami, by przedostać się z Jerozolimy do Ramallah, oddalonych od siebie o $10 \mathrm{~km}$. Palestyńczycy zrezygnowali z kontaktów z innymi ludźmi, odwiedzenie bowiem rodziny w innej części Zachodniego Brzegu zajmowało kilka dni, choć uprzednio trwało nie dłużej niż godzinę. Wielu Izraelczyków również obawiało się wychodzić w domu ze strachu przed zamachami samobójczymi. Autorka kolejny raz przekonała się, że istnieje przepaść między realiami życia na miejscu — zarówno Izraelczyków, jak i Palestyńczyków - a ich wizerunkiem $w$ zachodnich mediach i pracach naukowych głównego nurtu ${ }^{18}$. Nekrowładza (necropower) wiąże się z terytorializacją, czyli wytwarzaniem granic i hierarchii, stref i enklaw, zmianą w sferze własności, pozyskiwaniem zasobów czy produkowaniem szerokiego spektrum wyobrażeń kulturowych ${ }^{19}$.

Nie należy przeceniać znaczenia mediów newsowych w kreowaniu wizerunku konfliktu izraelsko-palestyńskiego, jest on bowiem wzmacniany przez Hollywood. Przemysł filmowy w Stanach Zjednoczonych wpisuje Palestyńczyków w kategorię uogólnionych

16 Ibidem, s. 116-119.

17 Ibidem, s. 120-123.

18 M. Carter Hallward, Struggling for a Just Peace. Israeli and Palestinian Activism in the Second Intifada, Gainsville FL 2011, s. 1.

19 M. Mbembe, op. cit., s. 25-26. 
przedstawień Arabów i muzułmanów (błędnie utożsamiając obie kategorie). Za Jackiem G. Shaheenem powtórzmy, że amerykańskie filmy w zdecydowanej większości ukazują Arabów w sposób wypaczający na wszelkie sposoby zarówno arabskich mężczyzn, kobiety, jak i dzieci. Ich analiza ukazuje systematyczną, wszechogarniającą i bezpardonową degradację i dehumanizację ludzi. Filmowy Arab pozostaje tym, czym zawsze był: kulturalnym Innym. Oglądani przez zniekształcone hollywoodzkie okulary Arabowie wyglądają groźnie. Reżyserowie kolektywnie portretują wszystkich Arabów jako wroga publicznego numer jeden: brutalnych, bezdusznych, barbarzyńskich fanatyków religijnych, szalonych na punkcie pieniędzy kulturalnych Innych, ze skłonnością do terroryzowania cywilizowanych ludzi Zachodu, zwłaszcza chrześcijan i żydów ${ }^{20}$.

Dodajmy jednak, że błędem byłoby wyłączne skupianie się na euroamerykańskich wizerunkach konfliktu izraelsko-palestyńskiego, gdyż — zwłaszcza w krajach, w których muzułmanie stanowią większość ludności - istnieją diametralnie inne jego wizje. Przykładem tego może być turecki film z 2011 r. Dolina Wilków: Palestyna. Jest to opowieść o tureckich agentach służb specjalnych, nawiązująca do prawdziwych wydarzeń z 31 maja 2010 r., kiedy izraelscy komandosi dokonali na wodach międzynarodowych Morza Śródziemnego desantu na 6 statków, którymi płynęły 633 osoby chcące złamać morską blokadę Strefy Gazy. Na największym ze statków, tzw. Flotylli Wolności („Mavi Marmara"), komandosi napotkali opór i użyli broni, zabijając 9 Turków i raniąc kilkadziesiąt innych osób ${ }^{21}$. W filmie turecki agent Polat Alemdar (grany przez Muhammeda Necatiego Şaşmaza) i jego dwaj towarzysze mają za zadanie zemścić się na izraelskim generale, odpowiedzialnym za atak na flotyllę, i zabić jego rodaków. Film jest tak przesycony przemocą i „tendencjami propagandowymi” (jak ujęło to niemieckie stowarzyszenie kontroli filmowej), że w Niemczech — gdzie żyje duża społeczność o tureckich korzeniach dopuszczono go w dystrybucji wyłącznie dla osób dorosłych ${ }^{22}$. Wizerunek Żydów w Dolinie Wilków stanowi lustrzane odbicie wizerunków Arabów z filmów akcji z Chuckiem Norrisem (np. Delta Force): są brutalni — czego dowodzi choćby scena strzelania przez żołnierzy izraelskich w plecy skutych Palestyńczyków, odrażający (zarówno fizycznie, jak i moralnie) oraz tchórzliwi. W filmie tureccy agenci zabijają dziesiątki izraelskich żołnierzy, widzowie często mogą oglądać zakrwawione zwłoki na tle gwiazd Dawida namalowanych na sprzęcie wojskowym, zwykle chwilę później efektownie wybuchającym.

\section{Dwa oblicza terroru: cywilizowany i dziki}

Konflikt izraelsko-palestyński bardzo często wpisuje się w szersze ramy poznawcze współczesnych studiów nad bezpieczeństwem narodowym i międzynarodowym. Jak pisze Uri Ben-Eliezer, w literaturze przedmiotu pojawiły się liczne określenia, które miały

20 J.G. Shaheen, Reel Bad Arabs. How Hollywood Vilifies a People, Northampton MA 2001, s. 1-2.

21 E. Tucker, The Middle East in Modern World History, London-New York 2016, s. 355.

22 B.E. Çetin, The Paramilitary Hero on Turkish Television: A Case Study on Valley of the Wolves, Newcastle 2015, s. 72. 
na celu wskazanie nowego typu konfliktów militarnych. Należą do nich choćby: „nowe wojny”, „wojny ponowoczesne”, „wojny trzeciego typu”, „wojny tożsamościowe”, „konflikty o niskiej intensywności”, „małe wojny”, „wojny ograniczone”. W ich kontekście wspomina się o „nowych zagrożeniach”, „nowych lękach”, „nowych ryzykach”, „nowym terroryzmie” ${ }^{23}$. Nie negując, że takie podejście bywa owocne poznawczo, w tej części rozważań wykaże się, że konflikt ten można zrozumieć w kontekście wojen kolonialnych. Zdawał sobie z tego sprawę pierwszy premier Izraela i długoletni działacz żydowskich grup paramilitarnych, Dawid Ben Gurion, który stwierdził w roku 1956:

To normalne: my zajęliśmy ich kraj. [...] Był antysemityzm, naziści, Hitler, Auschwitz - ale czy to ich wina? Oni widzą tylko jedno: my tu przyszliśmy i odebraliśmy im kraj. Dlaczego mieliby się z tym faktem pogodzić? [...] Zatem sprawa jest prosta: musimy być silni i utrzymywać potężną armię ${ }^{24}$.

Gwoli ścisłości: przemoc na terytorium Palestyny poprzedza powstanie Izraela. W latach 1936-1939 na obszarze brytyjskiego terytorium mandatowego doszło do powstania arabskiego, wymierzonego w Brytyjczyków i osadników syjonistycznych. Brytyjskie władze kolonialne burzyły domy liderów oporu, a nawet całe dzielnice miast, co może przypominać późniejszą strategię izraelską. Ogółem liczba ofiar wynosiła: 5 tysięcy Arabów palestyńskich, 400 Żydów i 200 Brytyjczyków ${ }^{25}$.

Kolonialna okupacja Zachodniego Brzegu i Strefy Gazy epoki późnej nowoczesności ma cechy formacji terroru, którą Mbembe nazywa nekrowładzą. Pierwszym jej składnikiem jest dynamika terytorialnej fragmentacji i ekspansji osiedli. Celem tego jest uniemożliwienie ruchu i wdrożenie separacji przypominającej państwo apartheidu. Terytoria okupowane są podzielone na izolowane komórki. Można zatem uznać, że okupacja ma charakter rozszczepiony (splintering occupation) ${ }^{26}$.

$\mathrm{Z}$ perspektywy infrastruktury rozszczepiona forma okupacji wiąże się z siecią szybkich dróg, mostów i tuneli, oddzielających Izraelczyków od Palestyńczyków. Kluczowe znaczenie ma okupacja przestrzeni powietrznej - kontrolują ją Izraelczycy za pomocą sensorów umieszczonych na dronach, samolotów zwiadowczych, śmigłowców bojowych i satelitów: zabijanie ma mieć charakter precyzyjny. Precyzji towarzyszy jednocześnie taktyka średniowiecznej wojny oblężniczej, którą stosuje się w sieciach obozów uchodźców. Sabotaż społecznej i miejskiej infrastruktury wroga wiąże się z zajęciem zasobów ziemi i przestrzeni powietrznej. Innymi słowy, jest to wojna infrastrukturalna (infrastructural warfare). Helikoptery Apache nadzorują terytoria $\mathrm{z}$ powietrza i niekiedy są używane do zabijania, na powierzchni ziemi ich rolę pełnią uzbrojone buldożery Caterpillar D-9. Te dwie bronie odstraszające ustanawiają dominację technologiczną późnonowoczesnego terroru. Przypadek palestyński ilustruje współczesną okupację jako zestaw władzy dyscyplinującej, biopolitycznej i nekropolitycznej. Razem mają one zapewnić mocarstwu kolonialnemu absolutną dominację nad ludnością terytoriów okupowanych. Przypomnijmy, że stan oblężenia sam w sobie jest instytucją wojskową.

\footnotetext{
${ }^{23}$ U. Ben-Eliezer, Old Conflict, New War. Israel's Politics Toward Palestinians, New York 2012, s. 8.

24 Cyt. za: E. Jasiewicz, Podpalić Gazę, Warszawa 2011, s. 18.

25 Ibidem, s. 11.

26 M. Mbembe, op. cit., s. 27-28.
} 
Oblężone wsie i miasteczka są odcięte od reszty świata. Codzienna egzystencja zostaje zmilitaryzowana. Lokalni dowódcy wojskowi decydują o tym, kogo i kiedy zabić. Oblężeni są odcięci od źródeł utrzymania. Niewidoczne zabijanie uzupełnia bezpośrednie egzekucje ${ }^{27}$.

Jonathan Cook zwraca uwagę na powtarzający się schemat działania. Najpierw uzbrojeni cywile, zwykle religijni fanatycy, byli zachęcani od osiedlania się na terytorium wroga, aby otoczyć i sfragmentaryzować wspólnoty palestyńskie. Kiedy były one zabezpieczone, mniej zideologizowani Izraelczycy korzystali z zachęty w postaci tanich domów i nisko oprocentowanych kredytów. System wież i palisad (tower-and-stockade), niekiedy zwany w Izraelu nielegalnymi wysuniętymi placówkami (illegal outposts), niewielkimi satelitami głównych osiedli na Zachodnim Brzegu, z czasem został zalegalizowany. Izrael nie tylko zepchnął Palestyńczyków do klatek na wolnym powietrzu, ale wręcz przekształcił je w laboratoria, w których eksperymentuje się z desperacją Palestyńczyków, chcąc ich zmusić ostatecznie do emigracji. W gruncie rzeczy te eksperymenty zaczęly się wewnątrz Izraela, a po wojnie roku 1967 były eksportowane na terytoria okupowane. Palestyńskie cierpienia zostały uprzemysłowione poprzez godziny policyjne, punkty kontrolne, mury, systemy pozwoleń i inwigilacji, stworzenie przynoszącego duże dochody przemysłu bezpieczeństwa narodowego. Zajęte przez Izrael ziemie palestyńskie to poligon doświadczalny nowych metod walk miejskich, kontroli tłumu i gettoizacji, a także rozwoju technik unikania obserwatorów, takich jak dziennikarze czy pracownicy pomocowi ${ }^{28}$.

Izraelczycy przez dziesięciolecia starali się i nadal starają ujarzmić stawiających coraz wyraźniejszy opór Palestyńczyków. Symbolem tego mogą być wydarzenia z 1971 r., kiedy Ariel Szaron miał podporządkować sobie Strefę Gazy, co nazywał „antyterrorystyczną wojną partyzancką"29. Szaron podzielił Gazę na regularne sektory, każdy o boku długości mili lub dwóch, co miało ułatwić identyfikację i lokalizację bojowników palestyńskich. Jego żołnierze wtargnęli do obozów palestyńskich spychaczami, które miażdżyły prowizoryczne chałupy, zmuszając obawiające się śmierci kobiety i dzieci do ucieczki. W ten sposób Szaron zyskał przydomek „Buldożer”. Sprowadził on jednostkę komandosów o nazwie Sajeret Rimon, która zainicjowała kampanię terroru, zabijając palestyńskich bojowników. Członkowie tej jednostki przyznali, że od lipca 1971 do lutego 1972 r. zgładzili 104 Palestyńczyków (ich zdaniem - wyłącznie „terrorystów”) i uwięzili ponad 740. Jak zaznacza wieloletni korespondent amerykańskich mediów w Izraelu:

Szaron zyskał międzynarodową reputację pozbawionego sentymentów oprawcy izraelskich sił zbrojnych. Jako przedstawiciel władz okupacyjnych zobowiązany był na mocy konwencji genewskiej do ochrony ludności okupowanej Gazy. Nigdy jednak nie rozliczono go, ani jego podwładnych, z dokonywanych przez wiele miesięcy samowolnych egzekucji na podstawie danych wywiadowczych nie poddanych ocenie sądu ${ }^{30}$.

27 Ibidem, s. 28-30.

28 J. Cook, Dissapearing Palestine. Israel's Experiments in Human Despair, London-New York 2008, s. $5,7,8$.

29 P. Tyler, Twierdza Izrael. Zakulisowa historia elit wojskowych, które uparcie bronią się przed pokojem, Poznań 2014, s. 246.

30 Ibidem. 
Żołnierze izraelscy to regularna armia państwowa ze sztywnymi hierarchiami i łańcuchem dowodzenia. Innymi słowy, to wojsko „cywilizowane”, wysoko cenione za swe umiejętności. Pułkownik Richard Kemp, były dowódca sił brytyjskich w Afganistanie, stwierdził: „Żadna inna armia na świecie nie uczyniła więcej niż Izrael, aby uratować życie niewinnych cywilów w strefie walk”31. Palestyński adwersarz jest z kolei „niecywilizowany”, wręcz „dziki”, co ma ważne skutki, gdyż - jak się zakłada — nie tylko nie szanuje życia przeciwnika, ale również swojego. Jak w 1927 r. pisał oficer Elbridge Colby, u dzikich brak rozróżnienia między walczącymi i niewalczącymi. W walkach uczestniczą całe plemiona, co jest prymitywną metodą działań wojennych, gdyż dla narodów cywilizowanych podział na walczących i niewalczących to podstawa prowadzenia wojny. Wojny partyzanckie (guerilla warfare) cechują się tym, że biorą w nich udział wszyscy - nie tylko mężczyźni, ale też kobiety, a nawet dzieci. W takich sytuacjach uprawnione jest, aby - zachowując bezpieczeństwo oddziałów - wszystkich traktować jako wrogów ${ }^{32}$. Potwierdza to logika celowanych zabójstw, czyli dokonywanych przez Izrael pozasądowych egzekucji. Izraelski Sąd Najwyższy 28 stycznia 2002 r. odrzucił 3 petycje przeciwko celowanym zabójstwom, uznając, że nie łamią one ani izraelskiego, ani międzynarodowego prawa. Stwierdził, że rozróżnienie między walczącymi i cywilami nie ma zastosowania, gdyż „Istnieje trzecia kategoria, zwana terroryzmem, która jest wrogiem całej ludzkości”33.

Symbolem braku ucywilizowania bojowników palestyńskich, jak podkreślają Izraelczycy, jest stosowanie przez nich tzw. żywych tarcz czy ukrywanie instalacji wojskowych w otoczeniu cywilnym. W przypadku Gazy, jednego z najgęściej zaludnionych obszarów na świecie, ten drugi zarzut wydaje się - na płaszczyźnie ściśle terytorialnej - problematyczny. Kategoria żywych tarcz sama w sobie jest użyteczna, lecz należy ją ściśle dookreślić, aby nie zdejmowała $\mathrm{z}$ walczących stron troski o ograniczanie strat cywilnych. Kwestię tę komplikuje również czynnik dobrowolności. 3 listopada 2006 r. okrążeni przez Izraelczyków bojownicy Hamasu ukrywali się za kobietami - uczyniły to one z własnej woli. W lipcu 2006 r. izraelskie i palestyńskie grupy obrońców praw człowieka udokumentowały przypadek zmuszenia Palestyńczyków, by służyli za żywe tarcze w Beit Hanoun. Izraelczycy zawiązali oczy 6 cywilom (w tym 2 dzieciom), zmuszając ich, by stali przed domami cywilów, gdzie odbywały się rajdy izraelskich żołnierzy w północnej Gazie $^{34}$. Jak prowokacyjnie zauważa Butler:

Jeśli zabijane w ostrzale czy bombardowaniach fosforem palestyńskie dzieci stanowią ludzkie tarcze, to w istocie nie są one wcale dziećmi, a raczej elementem uzbrojenia, narzędziami, sprzętem wojskowym, który w rzeczy samej wspomaga i współuczestniczy w ataku na Izrael ${ }^{35}$.

31 R. Jones, British Commander: IDF most moral army world has ever known, „Israel Today” 24 lipca 2014, http://www.israeltoday.co.il/Default.aspx?tabid=178\&nid=24780 (dostęp: 30 sierpnia 2016).

32 E. Colby, How to fight savage tribes, „The American Journal of International Law” 21, 1927, nr 2, s. $281-282$.

33 U. Ben-Eliezer, op. cit., s. 118.

${ }^{34}$ Human Rights Watch statement on our November 22 press release, „Human Rights Watch” 15 grudnia 2006, https://www.hrw.org/news/2006/12/15/human-rights-watch-statement-our-november-22-press-release (dostęp: 30 sierpnia 2016).

35 J. Butler, op. cit., s. 34 . 
Głównym dowodem dzikości Palestyńczyków jest stosowanie przez nich zamachów samobójczych, których ofiarami padają głównie osoby cywilne (także arabscy obywatele Izraela). Abstrahując od oceny moralnej - jednoznacznie negatywnej - takich czynów, warto zastanowić się, dlaczego - choć regularne armie, włącznie z izraelską, zabijają znacznie więcej osób cywilnych niż terroryści, choć zwyczajowo zabitych i rannych określają mianem strat ubocznych (collateral damages) - zamachy samobójcze wzbudzają taką odrazę, zwłaszcza w świecie zachodnim. Wstręt wobec zamachów samobójczych, pisze Jacqueline Rose, jest zapewne w pewnym stopniu wynikiem niechęci względem niezbywalnej bliskości, jaka w ostatnich chwilach życia łączy sprawcę czy sprawczynię z ofiarami. Zamach samobójczy to akt pełnego pasji utożsamienia, swoistego śmiertelnego uścisku z wrogiem. W przypadku Palestyńczyków, którzy mają coraz mniej możliwości kontaktowania się z Izraelczykami, zamach samobójczy może być aktem największego zbliżenia $\mathrm{z}$ nimi ${ }^{36}$. Warto podkreślić, że na płaszczyźnie prakseologicznej zamachy samobójcze są nie tyle nieskuteczne, ile przeciwskuteczne: oburzają one opinię międzynarodową, alienują zwolenników pokoju wśród Izraelczyków, dają przyzwolenie na zdecydowane działania izraelskich sił bezpieczeństwa. Wobec powyższego tym bardziej trzeba spróbować zrozumieć - ale nie usprawiedliwić - ich sprawców i sprawczynie.

Niektóre wyjaśnienia są kuriozalne, zwłaszcza te dotyczące swoistego prania mózgów, czego wyrazem są 72 huryse (dziewice), które mają czekać w Raju na zamachowca. Dziewice są symbolem czystości, nie rozkoszy seksualnych. Jak ujął to psycholog Szafik Masala, pragnienie Raju jest świadectwem, że życie na ziemi jest piekłem ${ }^{37}$. Wielu Palestyńczyków żyje w warunkach, które czynią ich „żywymi umarłymi” (living dead) ${ }^{38}$. Są pozbawieni szacunku do siebie i tradycyjnej ostoi rodziny, czyli ojców (rutynowo upokarzanych i bitych przez żołnierki i żołnierzy izraelskich). Inna rzecz, że religijna gloryfikacja zamachów samobójczych ma dość wątłe podstawy — wielu teologów odrzuca je jako formę zakazanego $\mathrm{w}$ islamie samobójstwa ${ }^{39}$. Odpowiedź na pytanie, co motywuje samobójcze ataki i kim są ich sprawcy i sprawczynie, zapewne nigdy nie będzie ostateczna, lecz to pytanie samo w sobie jest niebezpieczne. Jeśli ataki samobójcze są natury politycznej, w takim razie konieczne są działania o charakterze politycznym. Jeśli są one wyrazem „perwersji”, ich sprawców można traktować jako „sektę przestępczą”, izolować i aresztować. Przez wiele lat izraelskie służby specjalne próbowały stworzyć profil typowego zamachowcy-samobójcy, lecz uznały, że te starania są daremne. Jak zaznacza Ejad El-Saradż, od lat zajmujący się pomocą psychologiczną mieszkańcom Gazy, dzieci, które doświadczyły tak wielu nieludzkich doznań, odpowiedzą w sposób równie nieludzki ${ }^{40}$. Możemy też wskazać na zjawisko, które można określić mianem

36 J. Rose, Deadly embrace, „London Review of Books” 26, 2004, nr 21, http://www.lrb.co.uk/v26/n21/ jacqueline-rose/deadly-embrace (dostęp: 30 sierpnia 2016).

37 Ibidem.

38 M. Mbembe, op. cit., s. 38.

39 Suicide bombers: Dignity, despair, and the need for hope, „Journal of Palestinian Studies” 2002, nr 4, s. $73-74$.

40 J. Rose, op. cit. 
nekropropagandy, kultu śmierci i zabijania. Kiedy po wybuchu drugiej intifady pytano palestyńskie dzieci, kim chcą być, odpowiadały, że męczennikami. Podczas intifady męczennicy i męczennice są gloryfikowani, uznawani za mścicieli pokrzywdzonych, a zatem romantycznych bohaterów ${ }^{41}$.

\section{Podsumowanie}

Powyższa analiza z oczywistych względów może być co najwyżej przyczynkiem do pogłębionych i poszerzonych studiów nad omawianym konfliktem. Jasne wydaje się, że tendencja do przedstawiania którejkolwiek ze stron jako moralnie wyższej jest błędem. Obecna, zwłaszcza wśród zachodniej lewicy radykalnej (niekiedy u autorów pochodzenia żydowskiego), tendencja do idealizacji Palestyńczyków jest nieuprawniona. Już Frantz Fanon zauważył, że:

Skolonizowany jest zawistny. Kolonizator o tym wie; przyłapuje jego ukradkowe spojrzenia i rozglądając się bacznie dokoła stwierdza cierpko: „Oni chcą zająć nasze miejsce”. To prawda, każdy skolonizowany przynajmniej raz dziennie marzy, żeby być na miejscu kolonizatora ${ }^{42}$.

Uri Avnery zauważył pewną prawidłowość. Emerytowani szefowie służb bezpieczeństwa Izraela (Szin Bet) stają się, co może się wydawać na pozór paradoksalne, rzecznikami działań na rzecz pokoju. Można to racjonalnie wyjaśnić. Agenci Szin Betu są jedynymi członkami establishmentu, którzy wchodzą w rzeczywisty, bezpośredni, codzienny kontakt z Palestyńczykami. Przesłuchują ich, niekiedy torturują, próbują uczynić informatorami. Zbierają informacje, penetrując najbardziej niedostępne elementy palestyńskiego społeczeństwa. „Wiedzą więcej — pisze Avnery - o Palestyńczykach niż ktokolwiek w Izraelu (a być może i w Palestynie)". Po latach służby dochodzą do wniosków, które umykają większości izraelskich polityków - naród palestyński istnieje, pragnie on niepodległości, jedynym rozwiązaniem konfliktu jest zaś powstanie państwa palestyńskiego. Izraelska telewizja wyemitowała film dokumentalny Oddźwierni, w którym wszyscy żyjący byli szefowie Szin Betu i Mosadu opowiadali się za rozwiązaniem dwupaństwowym, twierdząc, że pokój może zostać osiągnięty wyłącznie wtedy, kiedy Palestyńczycy uzyskają państwowość ${ }^{43}$.

Jak podkreśla niedawny szef Mosadu, Tamil Pardo - co ważne, sefardyjski Żyd z rodziny, która znalazła schronienie w Turcji po wypędzeniu ich z Hiszpanii 525 lat temu - Izraelowi nie zagraża żadne niebezpieczeństwo zewnętrzne. Realnym problemem jest podział, a raczej dramatyczne pęknięcie wewnątrz izraelskiego społeczeństwa, które może nawet doprowadzić do wojny domowej. Rozziew między Żydami aszkenazyjskimi (europejskimi) i mizrachijskimi (orientalnymi czy też arabskimi) pogłębia się.

41 Suicide bombers..., s. 72.

42 F. Fanon, Wyklęty lud ziemi, „Maoistowski Projekt Dokumentacyjny”, s. 17, https://maopd.files.wordpress.com/2012/07/wyklety-lud-ziemi-1961.pdf (dostęp: 30 sierpnia 2016).

43 U. Avnery, Israel's impending civil war, „London Review of Books Blog” 6 września 2016, http://www. lrb.co.uk/blog/2016/09/06/uri-avnery/israels-impending-civil-war/ (dostęp: 25 września 2016). 
Ci pierwsi są zwykle bardziej majętni, lewicowi lub liberalni, świeccy, opowiadają się za pokojem. Ci drudzy są generalnie biedniejsi, prawicowi i nacjonalistyczni, religijni. Ten podział był widoczny już na początku istnienia Izraela, lecz żywiono nadzieję, że uda się go przezwyciężyć, również dzięki mieszanym małżeństwom. Stało się inaczej: dzieci $\mathrm{z}$ mieszanych małżeństw, wkraczając $\mathrm{w}$ dorosłość, wybierały jedną ze stron, stając się jej zagorzałymi zwolennikami. Jakkolwiek prawica rządzi Izraelem (z pewnymi przerwami) od 1977 r., nadal uznaje się za rzecznika grupy dyskryminowanej, obwiniając za wszystko „stare (aszkenazyjskie) elity”. Aszkenazyjczycy, co warto podkreślić, nadal dominują w sferze kultury, środków masowego komunikowania czy w gospodarce, a także - przynajmniej obecnie - w korpusie generalskim. Jedynym, co spaja izraelskie społeczeństwo, jest jego armia, konflikt z Arabami, okupacja i nieustający stan wojenny ${ }^{44}$. Skoro społeczeństwo może łączyć nade wszystko czynnik zewnętrzny, to może być nim nie stan nekropolitycznych zmagań z Palestyńczykami, lecz zawarcie z nimi pokoju. Nie jest to $\mathrm{w}$ chwili obecnej prawdopodobne, lecz możliwe. Jak ujmuje to Shlomo Sand:

wszelkie obiekcje co do prawa do istnienia państwa izraelskiego oparte na równości obywatelskiej i politycznej wszystkich jego mieszkańców - czy to wysuwane przez radykalnych muzułmanów, utrzymujących, że to państwo trzeba zetrzeć z powierzchni ziemi, czy też syjonistów, ślepo utrzymujących, że jest to kraj światowego żydostwa - są nie tylko anachronicznym głupstwem, ale też gotowym przepisem na kolejną katastrofę $\mathrm{w}$ regionie ${ }^{45}$.

\section{Bibliografia}

Agamben G., Homo sacer. Suwerenna władza i nagie życie, Pruszyński i S-ka, Warszawa 2008.

Avnery U., Israel's impending civil war, „London Review of Books Blog” 6 września 2016, http://www.lrb. co.uk/blog/2016/09/06/uri-avnery/israels-impending-civil-war/ (dostęp: 25 września 2016).

Ben-Eliezer U., Old Conflict, New War. Israel's Politics Toward Palestinians, Palgrave Macmillan, New York 2012.

Butler J., Ramy wojny. Kiedy życie godne jest opłakiwania?, Instytut Wydawniczy Książka i Prasa, Warszawa 2011.

Carter Hallward M., Struggling for a Just Peace. Israeli and Palestinian Activism in the Second Intifada, University Press of Florida, Gainsville FL 2011.

Çetin B.E., The Paramilitary Hero on Turkish Television: A Case Study on Valley of the Wolves, Cambridge Scholars Publishing, Newcastle 2015.

Colby E., How to fight savage tribes, „The American Journal of International Law” 21, 1927, nr 2.

Cook J., Dissapearing Palestine. Israel's Experiments in Human Despair, Zed Books, London-New York 2008.

Elmasry M., Death in the Middle East: an analysis of how the New York Times and Chicago Tribune framed killings in the second Palestinian Intifada, http://www2.gsu.edu/ wwwaus/Elmasry2009.pdf (dostęp: 30 sierpnia 2016).

Fanon F., Wyklęty lud ziemi, „Maoistowski Projekt Dokumentacyjny”, https://maopd.files.wordpress.com/2012/07/ wyklety-lud-ziemi-1961.pdf (dostęp: 30 sierpnia 2016).

Foucault M., Narodziny biopolityki, Wydawnictwo Naukowe PWN, Warszawa 2011.

Foucault M., Urzadzanie ciał, czyli władza w epoce biopolityki, Wydawnictwo Naukowe PWN, Warszawa 2010.

44 Ibidem.

45 S. Sand, Kiedy i jak wynaleziono Ziemię Izraela. Od Ziemi Świętej do ojczyzny, Warszawa 2015, s. 28. 
Halper J., An Israeli in Palestine. Resisting Dispossession, Redeeming Israel, Pluto Press, London 2008.

Hossein-Zadeh I., The Political Economy of U.S. Militarism, Palgrave Macmillan, New York-Basingstoke 2006.

Human Rights Watch statement on our November 22 press release, „Human Rights Watch” 15 grudnia 2006, https://www.hrw.org/news/2006/12/15/human-rights-watch-statement-our-november-22-press-release (dostęp: 30 sierpnia 2016).

Jasiewicz E., Podpalić Gazę, Wydawnictwo W.A.B., Warszawa 2011.

Jones R., British Commander: IDF most moral army world has ever known, „Israel Today” 24 lipca 2014, http://www.israeltoday.co.il/Default.aspx?tabid=178\&nid=24780 (dostęp: 30 sierpnia 2016).

Lemke T., Biopolityka, Sic!, Warszawa 2010.

Lippmann W., Public Opinion, Harcourt, Brace and Company, New York 1922.

Mbembe A., Necropolitics, „Public Culture” 15, 2003, nr 1.

Philo G., Berry M., Bad News from Israel, Pluto Press, London-Sterling VA 2004.

Rose J., Deadly embrace, „London Review of Books” 26, 2004, nr 21, http://www.lrb.co.uk/v26/n21/jacqueline-rose/deadly-embrace (dostęp: 30 sierpnia 2016).

Sand S., Kiedy i jak wynaleziono Ziemię Izraela. Od Ziemi Świętej do ojczyzny, Dialog, Warszawa 2015.

Shaheen J.G., Reel Bad Arabs. How Hollywood Vilifies a People, Interlink, Northampton, MA 2001.

Suicide bombers: Dignity, despair, and the need for hope, „Journal of Palestinian Studies” 2002, nr 4.

Tucker E., The Middle East in Modern World History, Routledge, London-New York 2016.

Tyler P., Twierdza Izrael. Zakulisowa historia elit wojskowych, które uparcie bronia się przed pokojem, Rebis, Poznań 2014.

Viser M., Attempted objectivity. An analysis of the New York Times and Ha'aretz and their portrayals of the Palestinian-Israeli conflict, „The International Journal of Press/Politics” 2003, nr 8 (4).

\section{Israeli-Palestinian conflict. Necropolitics' analysis}

Keywords: Palestinians, Israel, political conflict, necropolitics

\section{Summary}

The aim of this paper is to analyze Israeli-Palestinian conflict from the perspective of the 'necropolitics' category (term coined by Achille Mbembe). Firstly, author describes mass media coverage of the conflict, especially pro-Israeli bias in the American and British media. Nevertheless, some media representations in the mostly Muslin countries (i.e. Turkey) are anti-Semitic. Second part is devoted to the realities on the ground in occupied Palestinian territories and the discoursive practices of perceiving violence of both sides: 'civilized' Israeli and 'uncivilised' Palestinian. In conclusion, there are some considerations about future developments in the conflict. 